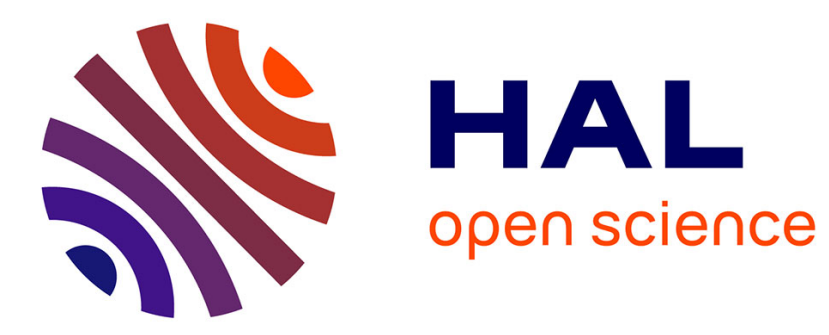

\title{
T Cell Populations and Functions Are Altered in Human Obesity and Type 2 Diabetes
}

\author{
Sothea Touch, Karine Clément, Sébastien André
}

\section{To cite this version:}

Sothea Touch, Karine Clément, Sébastien André. T Cell Populations and Functions Are Altered in Human Obesity and Type 2 Diabetes. Current Diabetes Reports, 2017, 17 (9), pp.81. 10.1007/s11892017-0900-5 . hal-01582558

\section{HAL Id: hal-01582558 https://hal.sorbonne-universite.fr/hal-01582558}

Submitted on 6 Sep 2017

HAL is a multi-disciplinary open access archive for the deposit and dissemination of scientific research documents, whether they are published or not. The documents may come from teaching and research institutions in France or abroad, or from public or private research centers.
L'archive ouverte pluridisciplinaire $\mathbf{H A L}$, est destinée au dépôt et à la diffusion de documents scientifiques de niveau recherche, publiés ou non, émanant des établissements d'enseignement et de recherche français ou étrangers, des laboratoires publics ou privés. 


\title{
T Cell Populations and Functions Are Altered in Human Obesity and Type 2 Diabetes
}

Sothea Touch ${ }^{1,2,3}$, Karine Clément ${ }^{1,2,3,4}$, Sébastien André $1,2,3, *$

\section{Author information:}

${ }^{1}$ INSERM, UMR_S 1166, Team 6 Nutriomics, 75013, Paris, France;

2 Sorbonne Universités, UPMC University Paris 06, UMR_S 1166, 75005, Paris, France;

${ }^{3}$ Institute of Cardiometabolism and Nutrition, ICAN, Pitié-Salpêtrière Hospital, Assistance Publique Hôpitaux de Paris, 75013, Paris, France;

${ }^{4}$ Assistance Publique Hôpitaux de Paris, Pitié-Salpêtrière Hospital, Nutrition, Endocrinology and Cardiology Departments, 75013, Paris, France;

\section{Corresponding author:}

* Dr Sébastien André, UMR_S 1166, Team 6 Nutriomics, Institute of Cardiometabolism and Nutrition

91 boulevard de l’Hôpital, F-75013, Paris, France

Tel: +33140779754

E-mail: sebastien.andre@upmc.fr

Keywords: obesity; type-2-diabetes; inflammation; T cell; Th17; MAIT

\begin{abstract}
Purpose of the Review: Obesity and type 2 diabetes (T2D) are considered chronic inflammatory diseases. While early publications have reported the implication of innate immune cells such as macrophages to promote systemic inflammation and metabolic dysfunctions, recent publications underline the alterations of the T cell compartment in human obesity and type 2 diabetes. These recent findings are the focus of this review.

Recent Findings: In humans, obesity and T2D induce the expansion of proinflammatory $\mathrm{T}$ cells such as CD4 Th1, Th17 and CD8 populations whereas innate T cells such as MAIT and iNKT cells are decreased. These alterations reflect a loss of total $\mathrm{T}$ cell homeostasis that may contribute to tissue and systemic inflammation.
\end{abstract}


Summary: Whether these changes are adaptive to nutritional variations and/or contribute to the progression of metabolic diseases remains to be clarified. T cell phenotyping may improve obese and/or T2D patient stratification with therapeutic and prognostic implications.

Keywords: Obesity, Type-2-diabetes, Inflammation, T cell

\section{Introduction}

Along with the obesity epidemic, the diabetes epidemic has dramatically increased worldwide. The insulin-resistant state that is often associated with obesity predisposes individuals to the development of type 2 diabetes (T2D). Additionally, obesity and T2D are both recognized as chronic, low-grade inflammatory diseases [1] characterized by increased circulating concentrations of inflammatory cytokines and acute-phase proteins that could contribute to systemic metabolic dysfunctions. In 1993, Hotamisligil et al. described that the expression and production of tumor-necrosis factor alpha (TNF- $\alpha$ ) were increased in the blood and in the adipose tissue (AT) in rodent models of obesity [2]. In this context, TNF- $\alpha$ is a proinflammatory cytokine known to activate intracellular transduction cascades that interfere with insulin signaling through the inhibition of insulin receptor substrate 1 (IRS-1) [3]. To establish the physiological role of TNF- $\alpha$ in obesity in the study from Hotamisligil et al., the authors showed that neutralizing TNF- $\alpha$ in obese mice ameliorates insulin sensitivity and glucose homeostasis. This study established for the first time the link between chronic inflammation and insulin resistance in obesity. Two years later, this finding was confirmed by the same group showing that TNF- $\alpha$ mRNA expression and circulating TNF- $\alpha$ was increased in human obesity and correlated with hyperinsulinemia [4]. Additional experiments performed in obese mice and humans showed that in addition to TNF- $\alpha$, chronic low-grade inflammation associated with obesity is characterized by the moderate elevation in circulation of inflammatory mediators such as $C$ reactive protein (CRP), serum amyloid A (SAA), proinflammatory cytokines including interleukin-6 (IL-6) and chemokines such as IL-8, CCL2/MCP-1 (C-C chemokine ligand 2/monocyte chemoattractant protein-1) and CCL5/RANTES (regulated on activation, normal $\mathrm{T}$ cell expressed and secreted) [5-7]. Following weight loss through caloric restriction or bariatric surgery, the circulating levels of these inflammatory mediators are decreased [5].

Obesity and T2D are also characterized by the recruitment of innate immune cells not only in metabolic tissues, predominantly adipose tissue, liver, muscle and pancreas but also in 
the intestine. Early studies focused on innate immunity and more specifically macrophage accumulation and low-grade inflammation in obese adipose tissue. These studies reported that macrophages might represent up to $40 \%$ of total AT cells [8,9]. Currently, growing emphasis is placed on adaptive immune cells present in adipose tissue. This is following the observation that $\mathrm{T}$ cell populations vary in proportion and phenotype [10,11]. As such, recent studies have started to investigate adaptive immunity, especially $\mathrm{T}$ cell phenotype, in the blood and metabolic tissues of persons with obesity and T2D. In this review, we will focus on human T cell subtypes and functions in these metabolic disorders.

\section{Conventional T Cell Subsets}

Classically, $\mathrm{T}$ cells are characterized by the surface expression of a $\mathrm{T}$ cell receptor (TCR) associated to a CD3 complex allowing signal transduction following antigen recognition by the TCR. Each TCR is usually composed of an $\alpha$ chain associated to a $\beta$ chain ( $\alpha \beta$ TCR). Two subsets of $\alpha \beta \mathrm{T}$ cells can be identified: $\mathrm{CD}^{+} \mathrm{T}$ helper cells (Th) and $\mathrm{CD}^{+}$cytotoxic $\mathrm{T}$ cells, which recognize peptides presented by the major histocompatibility complex (MHC) class II and I, respectively.

One of the early studies exploring $\mathrm{T}$ cells in obesity showed that mRNA levels of CD3 and RANTES, which plays a role in the recruitment of immune cells, were positively correlated in human visceral AT [12]. Additional studies have shown that the number of total $\mathrm{CD}^{+}, \mathrm{CD}^{+}$, and $\mathrm{CD}^{+} \mathrm{T}$ cells is increased in the adipose tissue in obese subjects, with a positive correlation between $\mathrm{T}$ cell accumulation and the level of adiposity [13]. In the clinical setting, the number of circulating immune cells is easily measurable, and several studies demonstrate that the CD4, CD8, and total lymphocytes are increased in the blood of persons with obesity and positively correlate with body mass index (BMI) [14]. Recently, using jejunal biopsies of subjects with severe obesity, our team has shown that the mRNA expression and number of $\mathrm{CD}^{+} \mathrm{T}$ cells are increased in the epithelium when compared to lean individuals' jejunal samples without impact of type-2-diabetes [15••]. Along with this increased density, we observed a relocation of $\mathrm{T}$ cells toward the epithelium in metabolically healthy obese, obese, and obese diabetic subjects.

\section{CD4 $^{+}$T Cell Diversity}

CD4 T cells can be polarized into distinct subsets with specific effector functions depending on the cytokine environment during antigenic challenge. These subsets can be identified 
according to the expression of specific transcription factors and their cytokine secretion profile. T helper subsets include Th1 and Th17 cells, which produce proinflammatory cytokines. Specifically, Th1 cells produce IFN- $\gamma$ and TNF- $\alpha$, while Th17 cells produce IL-17 and IL-22. Recently, Th22 cells were discovered and can also produce IL-22 in the absence of IL-17. Anti-inflammatory T cells also include Th2 cells, which produce IL-4 and IL-13, and regulatory $\mathrm{T}$ cells (Tregs), which maintain immune homeostasis by controlling immune cell activation and produce the anti-inflammatory cytokines IL-10 and TGF- $\beta$.

\section{Proinflammatory Th1/Th17/Th22}

Concordant observations have been made in human and murine adipose tissue with regard to proinflammatory Th1, Th17 and Th22 cells. Proinflammatory Th1 cells producing IFN- $\gamma$ are correlated with adiposity in adults [16, 13, 17, 18] and children with obesity [19]. Th1 cells are also upregulated in the adipose tissue and blood of patients with T2D [20]. In murine models of obesity, Th1 cells induce insulin resistance [21]. There is also a proinflammatory polarization of $\mathrm{T}$ cells in the colon and small intestine with increased number and/or frequency of IFN- $\gamma$-producing Th1, while anti-inflammatory Tregs are decreased [22, 23].

The pro-inflammatory cytokine IL-17 is increased in the blood of persons with obesity [24] and T2D [25, 26], and decreased after improvements in glucose homeostasis by therapeutic interventions (metformin treatment, dietary modifications, and exercise) [27]. Along with Th1 and Th17 cells, Th22 frequencies are also increased in the blood of persons with obesity and T2D compared to controls [28•, 29]. Interestingly, high levels of Th22 are positively correlated with HOMA-IR, which provides a phenotypic distinction between metabolically healthy persons with obesity and subjects with T2D. Unlike Th22, there is no association between HOMA-IR and circulating Th1 or Th17 cells.

In subcutaneous AT, IL-17 gene expression in $\mathrm{CD}^{+} \mathrm{T}$ cells is increased in both overweight and obese subjects compared to lean individuals [30]. We, and others, have reported the accumulation of IL-17- and IL-22-producing CD4 T cells in the subcutaneous and visceral adipose tissue of insulin-resistant obese subjects compared to normal insulinsensitive and lean subjects [31••, 32]. These findings suggest that obesity is associated with a Th17 switch. We highlighted a proinflammatory paracrine dialogue between macrophages and $\mathrm{CD} 4^{+} \mathrm{T}$ cells via the secretion of IL-1 $\beta$ and IL-17/IL-22 secreted by Th17/Th22 which is increased in obese persons with T2D and decreased after Roux-en-Y gastric bypass (RYGB)induced weight loss [31••]. We also reported that adipose tissue Th17 cells are increased in persons with obesity and positively correlated with HbA1c, suggesting a relationship with 
blood glucose control. Whether this phenomenon is causally associated with metabolic deterioration or an adaptive response is currently unknown.

Other interesting observations were made in the intestine. Studies in mice demonstrate that Th17 cells are decreased in the colon or ileum of obese mice fed a high fat diet (HFD) [33, 34, 23]. Garidou et al. showed that the decrease of Th17 in the ileum is associated with a decrease of segmented filamentous bacteria, which is known to induce Th17 responses [23]. Other studies also confirmed a decrease of Th17 in the intestine of obese mice [33, 34]. Despite these observations, one study reported that the frequency of Th17 cells remains unchanged in the small intestine and colon of obese mice versus lean mice [22]. The intestinal immune profile of obese and diabetic individuals was unknown until our team explored the phenotype of small intestinal T cells in the jejunal absortive segment in obese patients [15••].

In this study, we found that jejunal lamina propria of persons with obesity display higher mRNA expression of IL-17 and IL-22 compared to lean individuals. After ex vivo stimulation, unlike data observed in mouse models, we confirmed that jejunal $\mathrm{CD}^{+} \mathrm{T}$ cells producing not only IL-17 but also IL-22 are increased in obesity. T cell secretions, including IL-17 and IL-22, of obese but not lean individuals are able to inhibit insulin responses in Caco-2/TC7 enterocytes. In line with these experiments, IL-17 and IL-22 inhibit glucose uptake in rat skeletal muscle, and IL-17 reduces insulin sensitivity in cultured human hepatocytes and adipocytes and inhibits mouse adipocyte differentiation [32, 35, 36]. Based on these data, tissue context-dependent functions of IL-17 and IL-22 especially in insulin sensitive tissues and their pathological relevance remain to be fully elucidated, as well as potential differences between humans and rodents.

\section{Regulatory T Cells}

In humans, the number of circulating $\mathrm{CD} 25^{+} \mathrm{Foxp}^{+}$Tregs appears to be decreased in subjects with obesity compared to lean subjects and negatively correlated to BMI and plasma leptin level [37, 38]. Tregs are also decreased in the blood of patients with T2D compared to nondiabetic subjects while Th1 and Th17 are increased, suggesting a proinflammatory switch of $\mathrm{T}$ cells in T2D [25, 26]. The Th1/Tregs ratio is positively correlated with BMI [25]. In contrast with these findings, several studies report that the mRNA expression of the transcription factor Foxp3, a specific marker of Tregs, is increased in the adipose tissue of obese patients compared to lean subjects [39, 40]. This increase is accompanied with increased production of IL-10 and TGF- $\beta$ that are correlated with an increased production of proinflammatory IL-6 and TNF- $\alpha$ in the AT [40]. However, flow cytometry analysis of Tregs 
using CD25 and CD127 markers showed a decrease proportion of CD25 ${ }^{+}$CD127- ${ }^{-}$Tregs among $\mathrm{CD}^{+} \mathrm{T}$ cells in the visceral AT of metabolically unhealthy subjects with obesity compared to lean [41]. In the intestinal mucosa, studies with obese mouse models all show decreased proportion of $\mathrm{CD}^{+} \mathrm{Foxp}^{+}$Tregs and increased Th1/Tregs ratio compared to control mice $[22,23]$. Notably, in one of these studies, similar findings were observed in seven patients with obesity compared to 7 lean individuals in the lamina propria of colon and ileum resections from patients with tumors [22].

\section{CD8 $^{+}$T Cells}

Classically, $\mathrm{CD}^{+} \mathrm{T}$ cells play an important role in anti-viral and anti-tumoral immunity through their secretion of proinflammatory cytokines such as IFN- $\gamma$ and TNF- $\alpha$ and cytolytic action (granzyme, perforin, and Fas-induced apoptosis). In the adipose tissue, similar to CD3 ${ }^{+}$ $\mathrm{T}$ cells, the number of cytotoxic $\mathrm{CD}^{+} \mathrm{T}$ cells is increased in diet-induced obese and ob/ob mice [42], and the accumulation of these cells induces inflammation and insulin resistance [43]. Evidence of their pathophysiological role in metabolism comes from the genetic depletion of $\mathrm{CD}^{+} \mathrm{T}$ cells inducing lower macrophage infiltration, adipose tissue inflammation, and amelioration of systemic insulin resistance. Importantly, these inflammatory and metabolic deteriorations were reverted after adoptive transfer of $\mathrm{CD}^{+} \mathrm{T}$ cells to the CD8-deficient mice [42]. Among total T cells in the human intestine, we describe increased numbers of $\alpha \beta$ CD8 $\mathrm{T}$ cells in the jejunal lamina propria and epithelium in unhealthy subjects with obesity. This is characterized further by an increase of IFN- $\gamma$ producing $\mathrm{CD}^{+} \mathrm{T}$ cells in the lamina propria of obese versus lean subjects, suggesting a proinflammatory shift of CD8 T cells in the intestine of individuals with obesity [15••]. Albeit in a smaller population, another study also confirms this proinflammatory shift with an increased number of $\mathrm{CD}^{+} \mathrm{T}$ cells in the colon and small intestine of persons with obesity [22]. Additionally, in our study, we found that the density of $\mathrm{CD}^{+} \mathrm{T}$ cells or $\mathrm{CD}^{+} \mathrm{T}$ cells, depending on location, is correlated with markers of systemic inflammation (CRP and leukocytes counts), body weight (BMI, leptin), lipid parameters, and hepatic parameters (ASAT, ALAT, GGT, NAS score), suggesting links between the inflammatory profile of the intestine and patients' metabolic conditions [15••].

\section{Unconventional T Cells: Bridging Innate and Adaptive Immunity}


Most studies of $\mathrm{T}$ cells have focused on conventional $\mathrm{T}$ cells recognizing the highly polymorphic MHC molecules in a complex with peptides. However, other T cell types are not restricted to classical MHC molecules [44]. These subsets of T cells, called unconventional T cells, have a more limited TCR diversity and, unlike conventional T cells, can respond rapidly upon antigen encounter. These subsets include natural killer $\mathrm{T}$ (NKT) cells, mucosalassociated invariant T (MAIT) cells, and $\gamma \delta$ T cells.

\section{iNKT Cells}

Unlike conventional T cells recognizing MHC-peptide complexes, NKT cells bind to lipid antigens presented by the non-polymorphic molecule CD1d, which is expressed on the surface of antigen-presenting cells [45]. NKT cells are related to natural killer (NK) cells as they share phenotypic markers such as CD161, but they recognize their specific antigen by a TCR. Three groups of NKT cells can be distinguished according to their antigen specificity and TCR: invariant NKT (iNKT), type II NKT, and NKT-like lymphocytes. In humans, iNKT are predominant and express a semi-invariant TCR $\alpha$ chain $\mathrm{V} \alpha 24 \mathrm{~J} \alpha 18$ associated to a limited number of $\mathrm{V} \beta$ chains (usually V $\beta 8$ ) allowing iNKT cells to recognize glycosphingolipids presented by CD1d [46]. Upon activation, iNKT cells can secrete high amounts of cytokines including IL-4 and IFN- $\gamma$. In humans, iNKT cells can be identified with CD1d tetramers loaded with the glycolipid $\alpha$-Galactosylceramide and/or anti-V $\alpha 24 \mathrm{~J} \alpha 18$ antibodies. Studies have shown that compared to blood samples, iNKT are enriched in the visceral AT, where they represent up to $15 \%$ of total leukocytes [47, 48]. Adipose iNKT cells exhibit a strong cytotoxic potential and rapid cytokine production. In subjects with severe obesity, the frequency of iNKT cells is decreased in the visceral AT and increased after weight loss induced by RYGB although their frequency remains lower as compared to lean subjects [47]. The precise role of iNKT cells in human obesity and T2D remains to be elucidated. Indeed, if iNKT are decreased in human AT, studies examining iNKT depletion in mouse models indicate contradictory results, showing either amelioration, no effect, or aggravation of inflammation and insulin resistance [49].

\section{MAIT Cells}

Similar to NKT cells, mucosal-associated invariant T (MAIT) cells constitute a population of non-conventional $\mathrm{T}$ cells first described in the intestinal mucosa [50] and present in the blood (1-10\% of total T cells), lungs, adipose tissue [51•, 52••], and abundantly in the liver [53-55]. MAIT cells express the invariant TCR V $\alpha 7.2-\mathrm{J} \alpha 33$ associated to a limited number of V $\beta$ 
segments (V $\beta 2$ and V $\beta 13$ in humans). This allows MAIT cells to recognize ligands derived from the vitamin B2 (riboflavin) biosynthesis pathway in bacteria presented by the nonpolymorphic MHC-related protein 1 (MR1) [56-59]. MAIT cells can be activated by many bacteria species [60] and are absent in germ-free mice [50], suggesting their role in antimicrobial immunity [61, 62]. Upon TCR activation, MAIT cells produce large amounts of cytokines including IFN- $\gamma$, TNF- $\alpha$, granzyme B, perforin, IL-17, and IL-22. Circulating MAIT cells decrease with age [63-65] and are decreased in several pathologies, including infectious diseases (HIV, cholera, HCV) [66], autoimmune diseases (multiple sclerosis, lupus, rheumatoid arthritis) [67], and inflammatory bowel diseases (Crohn's disease, ulcerative colitis) [68]. Our team and others have recently shown that MAIT cell frequency is also decreased in the blood of obese, obese diabetic, and non-obese type 2 diabetic patients compared to lean non-diabetic controls [51•, 52••]. MAIT cell frequency is negatively correlated with BMI. Among obese subjects with T2D, we observed an increased expression of activation markers CD25 and CD69 compared to controls, suggesting an impact of obesity and T2D on MAIT cell activation. The secretion profile of circulating MAIT cells after ex vivo stimulation indicates increased production of Th1 and Th17-related cytokines in obesity and T2D. In line with our experiments, another study led by Carolan et al. also showed that MAIT cell frequency is decreased in adult and childhood obesity with a higher production of IL-17. In their study, MAIT cell dysregulation is positively correlated with the severity of insulin resistance, which is in agreement with our observations [51•]. Finally, these authors demonstrated that the frequency of MAIT cells is decreased also in the AT of obese individuals compared to lean one [51•]. Altogether, these findings showing reduced level of MAIT cells in obesity and T2D identify this specific T cell subset as potential marker of metabolic alterations. In addition, loss of MAIT cells might exert a deleterious effect through yet unidentified molecular mechanisms.

\section{$\gamma \delta$ T Cells}

$\gamma \delta \mathrm{T}$ cells constitute another subset of unconventional $\mathrm{T}$ cells representing $1-10 \%$ of circulating $\mathrm{T}$ cells in humans and mice. They express a TCR composed of a $\gamma$ chain associated to a $\delta$ chain ( $\gamma \delta$ TCR) instead of the usual $\alpha \beta$ TCR, and the number of genes encoding the variable segments is more limited for $\gamma \delta$ TCR compared to their $\alpha \beta$ TCR counterparts. Upon TCR activation, $\gamma \delta$ T cells respond by secreting cytokines such as IFN- $\gamma$, TNF- $\alpha$, and IL-17. A recent study has shown that $\mathrm{V} \gamma 9 \mathrm{~V} \delta 2 \mathrm{~T}$ cells are decreased in the circulation of obese subjects and negatively correlated with BMI [69]. Moreover, in obesity, $\gamma \delta$ T cells are more 
sensitive to apoptosis and have a reduced ability to secrete IFN- $\gamma$ during viral infections [69]. In the intestine of mice, $\gamma \delta \mathrm{T}$ cells are a major source of IL-17. In the context of murine obesity, 12-16 weeks of high-fat diet feeding induces increased frequency of IL-17-producing $\gamma \delta \mathrm{T}$ cells in the colon and small intestine lamina propria [22]. Our team has also explored the frequency of $\gamma \delta \mathrm{T}$ cells in the jejunal lamina propria and epithelium of subjects with obesity compared to lean individuals; however, we found no difference in the frequency of $\gamma \delta \mathrm{T}$ cells among total lymphocytes in severe obesity [15••]. Despite these above findings, the functional role and cytokine production of intestinal $\gamma \delta$ T cells remains to be explored in human obesity.

\section{Conclusions}

While obesity and T2D are tightly linked, patients exhibit different medical trajectories and complications. Both diseases share similar T cell compartment alterations that may contribute to their accompanying metabolic disturbances. These compartmental alterations include increased $\mathrm{T}$ cell numbers, a shift of CD4 $\mathrm{T}$ cell subsets toward a proinflammatory phenotype, and a decrease of peripheral unconventional T cells (Table 1). A higher susceptibility to infections has been observed in obesity and T2D and could reflect a T cell homeostatic dysregulation rather than a general shift toward inflammation state [70, 71]. This is further illustrated by less effective vaccine responsiveness in individuals with obesity [72]. Together, these findings suggest that metabolic alterations in obesity and T2D may affect $\mathrm{T}$ cell differentiation, function, and survival. Accordingly, distinct metabolic programming is linked to the differentiation of CD4 T cells into Th1, Th2, Th17, and Treg subsets via nutrient signaling pathways. The increased production of adipokines such as leptin could reflect in part the alterations of CD4 $\mathrm{T}$ cell population. Leptin increases $\mathrm{T}$ cell proliferation and Th1/Th17 cytokine secretion and prevents apoptosis through the mTOR signaling pathway following antigen stimulation [73, 74].

Importantly, while human metabolic diseases are characterized by notable phenotypic heterogeneity, standardized immunophenotyping of circulating $\mathrm{T}$ cell subsets may have clinical relevance to stratify patients with obesity and T2D and more generally patients affected by metabolic disease-related comorbidities. Through using longitudinal studies, this would assist in identifying patients at increased risk for metabolic and cardiovascular complications. This is especially relevant to clinical studies with a control group due to limited availability of human metabolic tissue samples (fat, liver, intestine) from control subjects, while peripheral blood mononuclear cell collection is easily harvested from blood sampling. 
Despite significant progress in immunophenotyping in recent years, several issues are yet to be solved. We have to assess the physiological connection between the modulation of circulating $\mathrm{T}$ cell phenotype and tissue metabolic alterations in the same individual. The signals and mechanisms involved in obesity- and/or T2D-mediated modulations in T cell functions remain poorly documented. Understanding the role of specific $\mathrm{T}$ cell subsets and proinflammatory cytokines (such as IL-17 and IL-22) in obesity and T2D is required to evaluate their pathological relevance, also considering the fact that discrepancies exist between human and rodent observations. If immunological alterations in part mediate the development of obesity and/or T2D-related diseases, the identification of metabolic immune checkpoints may represent a great opportunity to develop personalized immunotherapy, as demonstrated by successful developments for cancer therapy [75].

In conclusion, we have recently discovered that patients with metabolic diseases could be stratified based on their immune status. Thus, there is now an emerging field linking metabolism and the immune system, which should lead to promising new therapeutic approaches in the treatment of metabolic diseases as well as other chronic inflammatory conditions.

\section{Acknowledgments}

The laboratory is supported by the European Union's Seventh Framework Program for research, technological development and demonstration under grant agreement HEALTH-F42012-305312 (METACARDIS), the French National Agency of Research (ANR-2014 OBEMAIT and ADIPOFIB) and French Foundation for Medical Research. Assistance PubliqueHôpitaux de Paris (APHP) is the promoter of the clinical investigations performed at the Human Research Nutrition Center by the authors mentioned in this review. The authors would like to thank Timothy Swartz (Institute of Cardiometabolism and Nutrition, Pitié- Salpêtrière Hospital, Paris) for manuscript language editing.

\section{Compliance with Ethical Standards}

\section{Conflict of Interest}

Sothea Touch, Karine Clément, and Sébastien André declare that they have no conflict of interest.

\section{Human and Animal Rights and Informed Consent}


This article describes results from studies with human subjects performed by the three authors. All reported studies have been previously published. An informed consent was obtained for all subjects The Ethics Committee (Comité de protection des personnes, CPP Ilede-France) approved the studies, which were conducted in accordance with the Helsinki Declaration and are registered in clinical trials. This article does not contain any studies with animal subjects performed by any of the authors.

\section{References}

Papers of interest, published recently, have been highlighted as:

- Of importance

•• Of major importance

1. Cancello R, Clément K. Is obesity an inflammatory illness? Role of low-grade inflammation and macrophage infiltration in human white adipose tissue. BJOG. 2006;113(10):1141-7. doi:10.1111/j.1471-0528.2006.01004.x.

2. Hotamisligil GS, Shargill NS, Spiegelman BM. Adipose expression of tumor necrosis factor-alpha: direct role in obesity-linked insulin resistance. Science. 1993;259(5091):87-91.

3. Hotamisligil GS, Peraldi P, Budavari A, Ellis R, White MF, Spiegelman BM. IRS-1mediated inhibition of insulin receptor tyrosine kinase activity in TNF-alpha- and obesityinduced insulin resistance. Science. 1996;271(5249):665-8.

4. Hotamisligil GS, Arner P, Caro JF, Atkinson RL, Spiegelman BM. Increased adipose tissue expression of tumor necrosis factor-alpha in human obesity and insulin resistance. J Clin Invest. 1995;95(5):2409-15.

5. Dalmas E, Rouault C, Abdennour M, Rovere C, Rizkalla S, Bar-Hen A et al. Variations in circulating inflammatory factors are related to changes in calorie and carbohydrate intakes early in the course of surgery-induced weight reduction. Am J Clin Nutr. 2011;94(2):450-8. doi:10.3945/ajcn.111.013771.

6. Hotamisligil GS. Inflammation and metabolic disorders. Nature. 2006;444(7121):860-7. doi:10.1038/nature05485.

7. Poitou C, Viguerie N, Cancello R, De Matteis R, Cinti S, Stich V et al. Serum amyloid A: production by human white adipocyte and regulation by obesity and nutrition. Diabetologia. 2005;48(3):519-28. doi:10.1007/s00125-004-1654-6. 
8. Weisberg SP, McCann D, Desai M, Rosenbaum M, Leibel RL, Ferrante AW. Obesity is associated with macrophage accumulation in adipose tissue. $\mathrm{J}$ Clin Invest. 2003;112(12):1796-808. doi:10.1172/JCI19246.

9. Xu H, Barnes GT, Yang Q, Tan G, Yang D, Chou CJ et al. Chronic inflammation in fat plays a crucial role in the development of obesity-related insulin resistance. $\mathrm{J}$ Clin Invest. 2003;112(12):1821-30. doi:10.1172/JCI19451.

10. Cipolletta D, Kolodin D, Benoist C, Mathis D. Tissular T(regs): a unique population of adipose-tissue-resident Foxp3+CD4+ $\mathrm{T}$ cells that impacts organismal metabolism. Semin Immunol. 2011;23(6):431-7. doi:10.1016/j.smim.2011.06.002.

11. Osborn O, Olefsky JM. The cellular and signaling networks linking the immune system and metabolism in disease. Nature medicine. 2012;18(3):363-74. doi:10.1038/nm.2627.

12. Wu H, Ghosh S, Perrard XD, Feng L, Garcia GE, Perrard JL et al. T-cell accumulation and regulated on activation, normal $\mathrm{T}$ cell expressed and secreted upregulation in adipose $\begin{array}{llll}\text { tissue in } & \text { obesity. } & \text { Circulation. }\end{array}$ doi:10.1161/CIRCULATIONAHA.106.638379.

13. Duffaut C, Zakaroff-Girard A, Bourlier V, Decaunes P, Maumus M, Chiotasso P et al. Interplay between human adipocytes and $\mathrm{T}$ lymphocytes in obesity: CCL20 as an adipochemokine and T lymphocytes as lipogenic modulators. Arteriosclerosis, Thrombosis, and Vascular Biology. 2009;29(10):1608-14. doi:10.1161/ATVBAHA.109.192583.

14. Womack J, Tien PC, Feldman J, Shin JH, Fennie K, Anastos K et al. Obesity and immune cell counts in women. Metabolism. 2007;56(7):998-1004. doi:10.1016/j.metabol.2007.03.008. 15.•• Monteiro-Sepulveda M, Touch S, Mendes-Sá C, André S, Poitou C, Allatif O et al. Jejunal T Cell Inflammation in Human Obesity Correlates with Decreased Enterocyte Insulin Signaling. Cell Metab. 2015;22(1):113-24. doi:10.1016/j.cmet.2015.05.020.

This work explores for the first time in a large cohort of obese and diabetic patients compared to lean individuals the phenotype of immune cells and notably $\mathrm{T}$ cells and their impact on enterocyte insulin sensitivity.

16. Kintscher U, Hartge M, Hess K, Foryst-Ludwig A, Clemenz M, Wabitsch M et al. Tlymphocyte infiltration in visceral adipose tissue: a primary event in adipose tissue inflammation and the development of obesity-mediated insulin resistance. Arteriosclerosis, Thrombosis, and Vascular Biology. 2008;28(7):1304-10. doi:10.1161/ATVBAHA.108.165100.

17. O'Rourke RW, Metcalf MD, White AE, Madala A, Winters BR, Maizlin II et al. Depotspecific differences in inflammatory mediators and a role for NK cells and IFN-gamma in 
inflammation in human adipose tissue. Int $\mathrm{J}$ Obes (Lond). 2009;33(9):978-90. doi:10.1038/ijo.2009.133.

18. Zeyda M, Huber J, Prager G, Stulnig TM. Inflammation correlates with markers of T-cell subsets including regulatory $\mathrm{T}$ cells in adipose tissue from obese patients. Obesity (Silver Spring). 2011;19(4):743-8. doi:10.1038/oby.2010.123.

19. Pacifico L, Di Renzo L, Anania C, Osborn JF, Ippoliti F, Schiavo E et al. Increased Thelper interferon-gamma-secreting cells in obese children. Eur $\mathrm{J}$ Endocrinol. 2006;154(5):691-7. doi:10.1530/eje.1.02138.

20. McLaughlin T, Liu L-F, Lamendola C, Shen L, Morton J, Rivas H et al. T-cell profile in adipose tissue is associated with insulin resistance and systemic inflammation in humans. Arteriosclerosis, Thrombosis, and Vascular Biology. 2014;34(12):2637-43. doi:10.1161/ATVBAHA.114.304636.

21. Winer S, Chan Y, Paltser G, Truong D, Tsui H, Bahrami J et al. Normalization of obesityassociated insulin resistance through immunotherapy. Nature medicine. 2009;15(8):921-9. doi:10.1038/nm.2001.

22. Luck H, Tsai S, Chung J, Clemente-Casares X, Ghazarian M, Revelo XS et al. Regulation of obesity-related insulin resistance with gut anti-inflammatory agents. Cell Metab. 2015;21(4):527-42. doi:10.1016/j.cmet.2015.03.001.

23. Garidou L, Pomié C, Klopp P, Waget A, Charpentier J, Aloulou M et al. The Gut Microbiota Regulates Intestinal CD4 T Cells Expressing ROR $\gamma$ t and Controls Metabolic Disease. Cell Metab. 2015;22(1):100-12. doi:10.1016/j.cmet.2015.06.001.

24. Sumarac-Dumanovic M, Stevanovic D, Ljubic A, Jorga J, Simic M, StamenkovicPejkovic D et al. Increased activity of interleukin-23/interleukin-17 proinflammatory axis in obese women. Int J Obes (Lond). 2009;33(1):151-6. doi:10.1038/ijo.2008.216.

25. Jagannathan-Bogdan M, McDonnell ME, Shin H, Rehman Q, Hasturk H, Apovian CM et al. Elevated proinflammatory cytokine production by a skewed $\mathrm{T}$ cell compartment requires monocytes and promotes inflammation in type 2 diabetes. J Immunol. 2011;186(2):1162-72. doi:10.4049/jimmunol.1002615.

26. Zeng C, Shi X, Zhang B, Liu H, Zhang L, Ding $W$ et al. The imbalance of Th17/Th1/Tregs in patients with type 2 diabetes: relationship with metabolic factors and complications. J Mol Med. 2012;90(2):175-86. doi:10.1007/s00109-011-0816-5.27. SumaracDumanovic M, Jeremic D, Pantovic A, Janjetovic K, Stamenkovic-Pejkovic D, Cvijovic G et al. Therapeutic improvement of glucoregulation in newly diagnosed type 2 diabetes patients is 
associated with a reduction of IL-17 levels. Immunobiology. 2013;218(8):1113-8. doi:10.1016/j.imbio.2013.03.002.

28. - Zhao R, Tang D, Yi S, Li W, Wu C, Lu Y et al. Elevated peripheral frequencies of Th22 cells: a novel potent participant in obesity and type 2 diabetes. PLOS ONE. 2014;9(1):e85770. doi:10.1371/journal.pone.0085770.

One of the first studies exploring Th22 subset and cytokine production in the blood of obese and type-2-diabetic patients.

29. Guo H, Xu BC, Yang XG, Peng D, Wang Y, Liu XB et al. A High Frequency of Peripheral Blood IL-22(+) CD4(+) T Cells in Patients With New Onset Type 2 Diabetes Mellitus. J Clin Lab Anal. 2016;30(2):95-102. doi:10.1002/jcla.21821.

30. Bertola A, Ciucci T, Rousseau D, Bourlier V, Duffaut C, Bonnafous S et al. Identification of Adipose Tissue Dendritic Cells Correlated With Obesity-Associated Insulin-Resistance and Inducing Th17 Responses in Mice and Patients. Diabetes. 2012;61(9):2238-47. doi:10.2337/db11-1274.

31.• Dalmas E, Venteclef N, Caer C, Poitou C, Cremer I, Aron-Wisnewsky J et al. T cellderived IL-22 amplifies IL-1 $\beta$-driven inflammation in human adipose tissue: relevance to obesity and type 2 diabetes. Diabetes. 2014;63(6):1966-77. doi:10.2337/db13-1511.

This paper provides new insights into the dialogue between macrophages and $\mathrm{T}$ cells through the secretions of IL-1 $\beta$ and Th17-derived cytokines in the obese adipose tissue.

32. Fabbrini E, Cella M, McCartney SA, Fuchs A, Abumrad NA, Pietka TA et al. Association between specific adipose tissue CD4+ T-cell populations and insulin resistance in obese individuals. Gastroenterology. 2013;145(2):366-74.e1-3. doi:10.1053/j.gastro.2013.04.010.

33. Cavallari JF, Denou E, Foley KP, Khan WI, Schertzer JD. Different Th17 immunity in gut, liver, and adipose tissues during obesity: the role of diet, genetics, and microbes. Gut Microbes. 2016;7(1):82-9. doi:10.1080/19490976.2015.1127481.

34. Cox LM, Yamanishi S, Sohn J, Alekseyenko AV, Leung JM, Cho I et al. Altering the intestinal microbiota during a critical developmental window has lasting metabolic consequences. Cell. 2014;158(4):705-21. doi:10.1016/j.cell.2014.05.052.

35. Zúñiga LA, Shen W-J, Joyce-Shaikh B, Pyatnova EA, Richards AG, Thom C et al. IL-17 regulates adipogenesis, glucose homeostasis, and obesity. J Immunol. 2010;185(11):6947-59. doi:10.4049/jimmunol.1001269.

36. Lee SH, Jhun J, Byun JK, Kim EK, Jung K, Lee JE et al. IL-17 axis accelerates the inflammatory progression of obese in mice via TBK1 and IKBKE pathway. Immunol Lett. 2017;184:67-75. doi:10.1016/j.imlet.2017.02.004. 
37. van der Weerd K, Dik WA, Schrijver B, Schweitzer DH, Langerak AW, Drexhage HA et al. Morbidly obese human subjects have increased peripheral blood CD4+ T cells with skewing toward a Treg- and Th2-dominated phenotype. Diabetes. 2012;61(2):401-8. doi:10.2337/db11-1065.

38. Wagner NM, Brandhorst G, Czepluch F, Lankeit M, Eberle C, Herzberg S et al. Circulating regulatory $\mathrm{T}$ cells are reduced in obesity and may identify subjects at increased metabolic and cardiovascular risk. Obesity (Silver Spring). 2013;21(3):461-8. doi:10.1002/oby.20087.

39. Travers RL, Motta AC, Betts JA, Bouloumie A, Thompson D. The impact of adiposity on adipose tissue-resident lymphocyte activation in humans. Int J Obes (Lond). 2015;39(5):7629. doi:10.1038/ijo.2014.195.

40. Pereira S, Teixeira L, Aguilar E, Oliveira M, Savassi-Rocha A, Pelaez JN et al. Modulation of adipose tissue inflammation by FOXP3+ Treg cells, IL-10, and TGF- $\beta$ in metabolically healthy class III obese individuals. Nutrition. 2014;30(7-8):784-90. doi:10.1016/j.nut.2013.11.023.

41. Esser N, L'homme L, De Roover A, Kohnen L, Scheen AJ, Moutschen M, Piette J, Legrand-Poels S, Paquot N. Obesity phenotype is related to NLRP3 inflammasome activity and immunological profile of visceral adipose tissue. Diabetologia. 2016;56(11):2487-97. doi: 10.1007/s00125-013-3023-9.

42. Rausch ME, Weisberg S, Vardhana P, Tortoriello DV. Obesity in C57BL/6J mice is characterized by adipose tissue hypoxia and cytotoxic T-cell infiltration. Int J Obes (Lond). 2008;32(3):451-63. doi:10.1038/sj.ijo.0803744.

43. Nishimura S, Manabe I, Nagasaki M, Eto K, Yamashita H, Ohsugi M et al. CD8+ effector $\mathrm{T}$ cells contribute to macrophage recruitment and adipose tissue inflammation in obesity. Nature medicine. 2009;15(8):914-20. doi:10.1038/nm.1964.

44. Godfrey DI, Uldrich AP, McCluskey J, Rossjohn J, Moody DB. The burgeoning family of unconventional T cells. Nat Immunol. 2015;16(11):1114-23. doi:10.1038/ni.3298.

45. Tard C, Rouxel O, Lehuen A. Regulatory role of natural killer T cells in diabetes. Biomed J. 2015;38(6):484-95. doi:10.1016/j.bj.2015.04.001.

46. Sugimoto C, Fujita H, Wakao H. Mucosal-associated invariant $\mathrm{T}$ cells from induced pluripotent stem cells: A novel approach for modeling human diseases. World J Stem Cells. 2016;8(4):158-69. doi:10.4252/wjsc.v8.i4.158.

47. Lynch L, Nowak M, Varghese B, Clark J, Hogan AE, Toxavidis V et al. Adipose tissue invariant NKT cells protect against diet-induced obesity and metabolic disorder through 
regulatory cytokine production. Immunity. 2012;37(3):574-87. doi:10.1016/j.immuni.2012.06.016.

48. Lynch L, O'Shea D, Winter DC, Geoghegan J, Doherty DG, O'Farrelly C. Invariant NKT cells and $\mathrm{CD} 1 \mathrm{~d}(+)$ cells amass in human omentum and are depleted in patients with cancer and obesity. Eur J Immunol. 2009;39(7):1893-901. doi:10.1002/eji.200939349.

49. Mathis D. Immunological Goings-on in Visceral Adipose Tissue. Cell Metab. 2013;17(6):851-9. doi:10.1016/j.cmet.2013.05.008.

50. Treiner E, Duban L, Bahram S, Radosavljevic M, Wanner V, Tilloy F et al. Selection of evolutionarily conserved mucosal-associated invariant $\mathrm{T}$ cells by MR1. Nature. 2003;422(6928):164-9. doi:10.1038/nature01433.

51. Carolan E, Tobin LM, Mangan BA, Corrigan M, Gaoatswe G, Byrne G et al. Altered distribution and increased IL-17 production by mucosal-associated invariant $\mathrm{T}$ cells in adult and childhood obesity. J Immunol. 2015;194(12):5775-80. doi:10.4049/jimmunol.1402945.

This is the first study exploring MAIT cells frequency in the adipose tissue of obese versus lean subjects; the authors show that MAIT cell frequency is decreased in the obese adipose tissue.

52.• Magalhaes I, Pingris K, Poitou C, Bessoles S, Venteclef N, Kiaf B et al. Mucosalassociated invariant $\mathrm{T}$ cell alterations in obese and type 2 diabetic patients. $\mathrm{J}$ Clin Invest. 2015;125(4):1752-62. doi:10.1172/JCI78941.

This paper reports that circulating MAIT cells are decreased in obesity and type-2-diabetic subjects with increased proinflammatory cytokine production.

53. Dusseaux M, Martin E, Serriari N, Péguillet I, Premel V, Louis D et al. Human MAIT cells are xenobiotic-resistant, tissue-targeted, CD161hi IL-17-secreting T cells. Blood. 2011;117(4):1250-9. doi:10.1182/blood-2010-08-303339.

54. Kurioka A, Walker LJ, Klenerman P, Willberg CB. MAIT cells: new guardians of the liver. Clin Trans Immunol. 2016;5(8):e98. doi:10.1038/cti.2016.51.

55. Tang X-Z, Jo J, Tan AT, Sandalova E, Chia A, Tan KC et al. IL-7 licenses activation of human liver intrasinusoidal mucosal-associated invariant $\mathrm{T}$ cells. $\mathrm{J}$ Immunol. 2013;190(7):3142-52. doi:10.4049/jimmunol.1203218.

56. Eckle SBG, Corbett AJ, Keller AN, Chen Z, Godfrey DI, Liu L et al. Recognition of Vitamin B Precursors and Byproducts by Mucosal Associated Invariant T Cells. J Biol Chem. 2015;290(51):30204-11. doi:10.1074/jbc.R115.685990. 
57. Franciszkiewicz K, Salou M, Legoux F, Zhou Q, Cui Y, Bessoles S et al. MHC class Irelated molecule, MR1, and mucosal-associated invariant $\mathrm{T}$ cells. Immunol Rev. 2016;272(1):120-38. doi:10.1111/imr.12423.

58. Kjer-Nielsen L, Patel O, Corbett AJ, Le Nours J, Meehan B, Liu L et al. MR1 presents microbial vitamin B metabolites to MAIT cells. Nature. 2012;491(7426):717-23. doi:10.1038/nature11605.

59. McWilliam HEG, Birkinshaw RW, Villadangos JA, McCluskey J, Rossjohn J. MR1 presentation of vitamin B-based metabolite ligands. Current Opinion in Immunology. 2015;34:28-34. doi:10.1016/j.coi.2014.12.004.

60. Le Bourhis L, Martin E, Péguillet I, Guihot A, Froux N, Coré M et al. Antimicrobial activity of mucosal-associated invariant $T$ cells. Nat Immunol. 2010;11(8):701-8. doi:10.1038/ni.1890.

61. Gold MC, Cerri S, Smyk-Pearson S, Cansler ME, Vogt TM, Delepine J et al. Human mucosal associated invariant $\mathrm{T}$ cells detect bacterially infected cells. PLOS Biology. 2010;8(6):e1000407. doi:10.1371/journal.pbio.1000407.

62. Napier RJ, Adams EJ, Gold MC, Lewinsohn DM. The Role of Mucosal Associated Invariant $\mathrm{T}$ Cells in Antimicrobial Immunity. Front Immunol. 2015;6:344. doi:10.3389/fimmu.2015.00344.

63. Hiejima E, Kawai T, Nakase H, Tsuruyama T, Morimoto T, Yasumi T et al. Reduced Numbers and Proapoptotic Features of Mucosal-associated Invariant $\mathrm{T}$ Cells as a Characteristic Finding in Patients with Inflammatory Bowel Disease. Inflamm Bowel Dis. 2015;21(7):1529-40. doi:10.1097/MIB.0000000000000397.

64. Lee OJ, Cho Y-N, Kee S-J, Kim M-J, Jin H-M, Lee S-J et al. Circulating mucosalassociated invariant $\mathrm{T}$ cell levels and their cytokine levels in healthy adults. Exp Gerontol. 2014;49:47-54. doi:10.1016/j.exger.2013.11.003.

65. Novak J, Dobrovolny J, Novakova L, Kozak T. The decrease in number and change in phenotype of mucosal-associated invariant $\mathrm{T}$ cells in the elderly and differences in men and women of reproductive age. Scandinavian Journal of Immunology. 2014;80(4):271-5. doi:10.1111/sji.12193.

66. Howson LJ, Salio M, Cerundolo V. MR1-Restricted Mucosal-Associated Invariant T Cells and Their Activation during Infectious Diseases. Front Immunol. 2015;6:303. doi:10.3389/fimmu.2015.00303.

67. Hinks TSC. Mucosal-associated invariant T cells in autoimmunity, immune- mediated diseases and airways disease. Immunology. 2016;148(1):1-12. doi:10.1111/imm.12582. 
68. Treiner E. Mucosal-associated invariant $\mathrm{T}$ cells in inflammatory bowel diseases: bystanders, defenders, or offenders? Front Immunol. 2015;6:27. doi:10.3389/fimmu.2015.00027.

69. Costanzo AE, Taylor KR, Dutt S, Han PP, Fujioka K, Jameson JM. Obesity Impairs $\gamma \delta$ T Cell Homeostasis and Antiviral Function in Humans. PLOS ONE. 2015;10(3). doi:10.1371/journal.pone.0120918.

70. Muller LM, Gorter KJ, Hak E, Goudzwaard WL, Schellevis FG, Hoepelman AI et al. Increased risk of common infections in patients with type 1 and type 2 diabetes mellitus. Clin Infect Dis. 2005;41(3):281-8. doi:10.1086/431587.

71. Paich HA, Sheridan PA, Handy J, Karlsson EA, Schultz-Cherry S, Hudgens MG et al. Overweight and obese adult humans have a defective cellular immune response to pandemic H1N1 influenza A virus. Obesity (Silver Spring). 2013;21(11):2377-86. doi:10.1002/oby.20383.

72. Tagliabue C, Principi N, Giavoli C, Esposito S. Obesity: impact of infections and response to vaccines. Eur J Clin Microbiol Infect Dis. 2016;35(3):325-31. doi:10.1007/s10096-015-2558-8.

73. Delgoffe GM, Pollizzi KN, Waickman AT, Heikamp E, Meyers DJ, Horton MR et al. The kinase mTOR regulates the differentiation of helper $\mathrm{T}$ cells through the selective activation of signaling by mTORC1 and mTORC2. Nat Immunol. 2011;12(4):295-303. doi:10.1038/ni.2005.

74. Procaccini C, De Rosa V, Galgani M, Carbone F, Cassano S, Greco D et al. Leptininduced mTOR activation defines a specific molecular and transcriptional signature controlling CD4+ effector $\mathrm{T}$ cell responses. J Immunol. 2012;189(6):2941-53. doi:10.4049/jimmunol.1200935.

75. Topalian SL, Taube JM, Anders RA, Pardoll DM. Mechanism-driven biomarkers to guide immune checkpoint blockade in cancer therapy. Nat Rev Cancer. 2016;16(5):275-87. doi:10.1038/nrc.2016.36. 
Table 1 Alterations of $\mathrm{T}$ cell populations in human obesity and type-2 diabetes

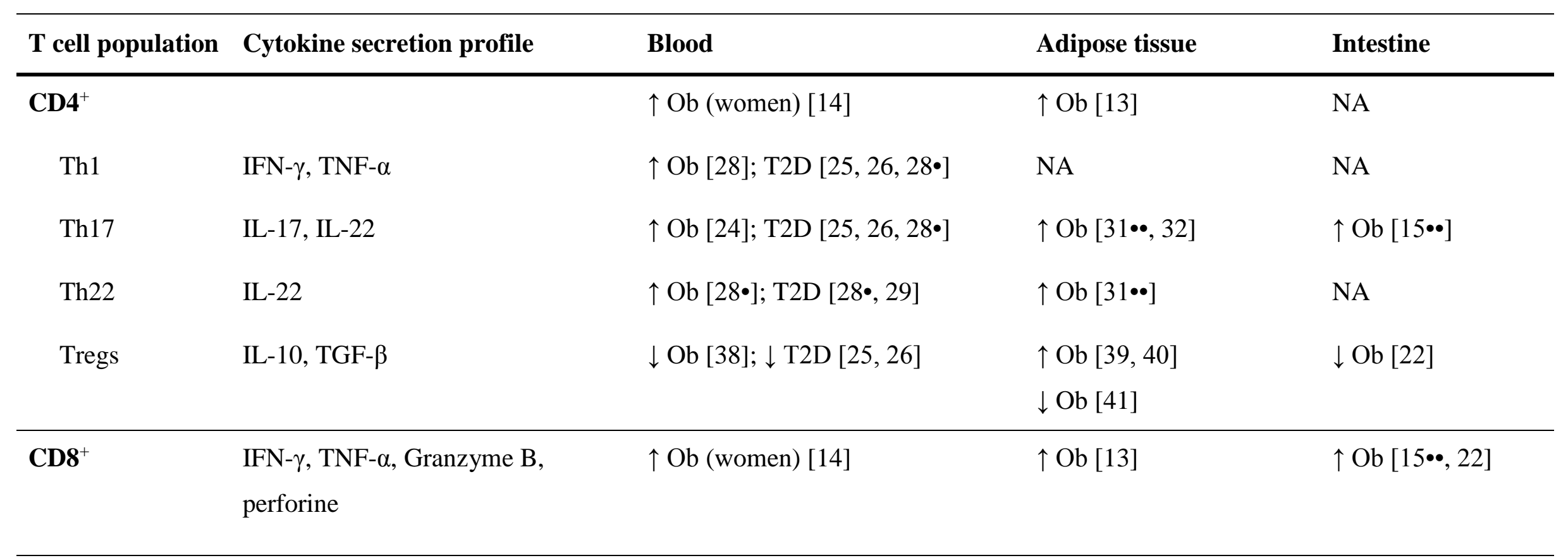

\section{Unconventional $\mathbf{T}$ cells}

\begin{tabular}{|c|c|c|c|c|}
\hline iNKT & IL-4, IFN- $\gamma$ & NA & $\downarrow \mathrm{Ob}[47,48]$ & NA \\
\hline MAIT & $\begin{array}{l}\text { IFN- } \gamma \text {, TNF- } \alpha \text {, Granzyme B, } \\
\text { perforine, IL-17, IL-22 }\end{array}$ & $\downarrow \mathrm{Ob}[51 \bullet, 52 \bullet \bullet] ; \mathrm{T} 2 \mathrm{D}[52 \bullet \bullet]$ & $\downarrow \mathrm{Ob}[51 \bullet]$ & NA \\
\hline$\gamma \delta$ & IFN- $\gamma$, TNF- $\alpha$, IL-17 & $\downarrow \mathrm{Ob}[69]$ & NA & $\leftrightarrow \mathrm{Ob}[15 \cdot \bullet]$ \\
\hline
\end{tabular}

Arrows indicate overall change of human T cell population frequency and/or numbers in the blood, adipose tissue or intestine in obesity or type 2 diabetes compared with lean non diabetic individual. $\uparrow$ indicates an increase, $\downarrow$, decrease, $\leftrightarrow$, no difference. Abbreviations: Ob obesity; MAIT mucosal-associated invariant T cell, $N A$ not available, $T 2 D$ type-2 diabetes, $T h$, T helper, Tregs regulatory T cells, $N K T$ natural killer T cell 